\title{
Autoantibodies in patients with juvenile chronic arthritis and their immediate family relatives
} T R Southwood, P J Roberts-Thomson, M J Ahern, K Shepherd, R McEvoy, J B Ziegler,
J Edmonds

\begin{abstract}
Antibodies to nuclear antigens were assessed in 23 children with juvenile chronic arthritis (JCA) and 66 of their first degree relatives. Serum samples from 16 patients with JCA $(70 \%)$ and nine relatives (14\%) had antinuclear antibodies by indirect immunofluorescence. Antibodies against nuclear antigens in rabbit thymus extract or an erythroblastoid cell line (K562) were detected by countercurrent immunoelectrophoresis and immunoblotting in 16 patients (70\%) and 39 family relatives (59\%). Immunoblotting did not show any banding patterns common to all patients with JCA, though bands in the $43-45 \mathrm{kD}$ range were detected in 5/23 patients. Anticardiolipin antibodies were found in 7/23 patients. In total, $18 / 20$ families $(90 \%)$ had members other than the probands with detectable autoantibodies. In five families immunoblotting showed common banding patterns between the probands and other members. This suggests that there might be an inherited trend towards autoimmune responses in some families of patients with JCA.
\end{abstract}

The pathogenesis of juvenile chronic arthritis (JCA) is poorly understood. The presence of antinuclear antibodies, ${ }^{1-4}$ anticollagen antibodies, ${ }^{5-8}$ anti-T-cell antibodies, ${ }^{9-11}$ rheumatoid factors, ${ }^{12-14}$ and other autoantibodies ${ }^{15} 16$ in patients with JCA suggests that an autoimmune process is taking place. In other autoimmune diseases, such as systemic lupus erythematosus and progressive systemic sclerosis, there seems to be an inherited tendency towards autoantibody formation, ${ }^{17-21}$ but, as far as we are aware, this has not been previously investigated in JCA.

Studies of familial patterns and HLA associations $^{22-29}$ have provided evidence for a genetic predisposition to JCA. There also seems to be an increased prevalence of autoimmune disease in the families of patients with $\mathrm{JCA},{ }^{30}$ but the prevalence of autoantibodies in these families has not been reported. In this study our first aim was to report the prevalence of antinuclear antibodies among 66 first degree relatives of 20 patients with JCA, and to determine if there were common patterns of these antibodies among family members.

The antigenic specificities of most antinuclear antibodies associated with JCA are undetermined, though there is evidence that some of the antinuclear antibodies are directed against histones. ${ }^{31} 32$ Our second aim was to clarify some of the cellular constituents to which autoantibodies are directed in patients with JCA by immunoblotting techniques. Our third aim was to investigate antibodies to cardiolipin in our patients with JCA by an enzyme linked immunosorbent assay (ELISA). This family of autoantibodies has a close clinical association with the presence of antinuclear antibodies.

\section{Patients and methods}

Twenty three patients with juvenile chronic arthritis $^{33}$ were arbitrarily selected from patients attending paediatric arthritis clinics. Eighteen children had pauciarticular onset JCA (14 girls, of whom nine also had chronic anterior uveitis, and four boys, only one of whom had chronic anterior uveitis). One girl had systemic onset disease and four children had polyarticular onset (three girls and one boy); none of these five patients had chronic anterior uveitis. Four patients were HLA-B27 positive (three boys and one girl with pauciarticular onset disease). All patients had had active disease for at least one year before the study, and most were taking non-steroidal anti-inflammatory drugs; several were also taking slow acting antirheumatic drugs (gold or penicillamine).

Serum samples from 66 immediate family members ( 20 families) of 20 patients with JCA were also studied. Samples were not available from any family members of the other three patients with JCA. Only one of the family members had an overt autoimmune disease (rheumatoid arthritis in an older sister of a patient). Blood was obtained by antecubital venepuncture in all instances, and the serum samples were stored in small aliquots at $-70^{\circ} \mathrm{C}$.

Antinuclear antibodies were measured by indirect immunofluorescence on HEp-2 cell line substrates by standard techniques. ${ }^{34}$ All serum samples were screened at a dilution of $1 / 40$ and a positive reaction recorded if nuclear fluorescence was seen at this dilution. Antibodies to extractable nuclear antigens were measured by counterimmunoelectrophoresis in $1 \%$ agarose using either rabbit thymus extract or the cell line K562 to provide nuclear antigenic material. Rheumatoid factor was assessed by latex agglutination (Behring). An ELISA was used to measure anticardiolipin IgG antibodies, as previously described. ${ }^{35}$

Antinuclear antibodies were characterised by a modification of the immunoblotting technique described by Towbin. ${ }^{36}$ Briefly, nuclear proteins from rabbit thymus extract or $\mathrm{K} 562$ were subjected to sodium dodecyl sulphate/polyacrylamide (12\%) gel electrophoresis and the separated proteins transferred to nitrocellulose 
Table 1 Prevalence of autoantibodies in families of patients with juvenile chronic arthritis*

\begin{tabular}{|c|c|c|c|c|c|}
\hline & \multirow{2}{*}{$\begin{array}{l}\text { Imanumo- } \\
\text { fluorescencet } \\
H E p-2\end{array}$} & \multicolumn{2}{|l|}{ CIEP¥ } & \multicolumn{2}{|c|}{ ImemunoblottingS } \\
\hline & & $\overline{R T E \|}$ & K562 & $\overline{R T E}$ & $K 562$ \\
\hline \multirow{3}{*}{$\begin{array}{l}\text { Number of families with } \\
\text { one positivef member } \\
\text { Number of families with } \\
\text { two positive members } \\
\text { Number of families with } \\
\text { three positive members }\end{array}$} & 5 & 4 & 7 & 5 & 9 \\
\hline & 2 & 2 & 6 & $\mathbf{0}$ & 3 \\
\hline & 0 & 0 & 1 & 0 & 0 \\
\hline $\begin{array}{l}\text { Total No (\%) positive of } \\
66 \text { relatives }\end{array}$ & 9 (14) & $8(12)$ & $22(33)$ & $5(8)$ & $15(23)$ \\
\hline
\end{tabular}

*Excluding the probands with juvenile chronic arthritis.

tIndirect immunofluorescence using HEp-2 substrate.

+Countercurrent immunoelectrophoresis using either RTE or K562 substrate.

Immunoblotting using either RTE or K562 substrate.

|RTE = rabbit thymus extract.

A positive family member had serological evidence of at least one autoantibody.

paper. After blocking with horse serum the nitrocellulose paper was cut into strips according to individual lanes of separated proteins, incubated with patients' serum samples, and washed. Any fixed IgG antibody was visualised with an avidin-biotin, alkaline phosphatase substrate system (Vector).

All the above immunological techniques were standardised and were in regular use in our department. Positive and negative internal controls were include in each assay, and regular participation in an external quality assurance programme in immunology (Royal College of Pathologists of Australasia) ensured close monitoring of the accuracy and precision of the techniques. Fisher's exact test (two tailed) was used for statistical analysis where appropriate.

\section{Results}

Eighteen of 20 families had at least one additional member (other than the proband with JCA) with serological evidence of autoimmunity (table 1). In one family four members had positive tests for autoantibodies; three members were positive in five families; two were positive in eight families; and one was positive in four families. In all, 39/66 family members $(59 \%)$ had one or more positive tests for autoantibodies. No positive tests for autoimmunity in the families could be significantly correlated with positive tests for autoimmunity in the patients.

Serum samples from 16 of the 23 patients with JCA were antinuclear antibody positive in this study. Nuclear fluorescence was homogeneous in 13 patients and speckled in three. Thirteen antinuclear antibody positive patients had pauciarticular onset disease (12 girls, one boy) and the other three (all girls) had polyarticular onset JCA. Only one of four B27 positive patients had antinuclear antibodies, and she also had antibodies to cardiolipin (table 2). Two female patients with polyarticular onset disease had low titre rheumatoid factor $(1 / 20)$, and $7 / 23$ patients (30\%) had antibodies to cardiolipin.

Fifteen of 23 patients (65\%) had antibodies to nuclear antigens by either counterimmunoelectrophoresis or immunoblotting against either rabbit thymus extract or K562 extract. The greatest prevalence of positive reactions $(10 / 23,43 \%)$ was elicited by immunoblotting using K562 (table 3). In only one patient could the antibodies to extractable nuclear antigens be characterised further; he had anti-Sm and later developed systemic lupus erythematosus. None of the other patients had antibodies directed against the nRNP, La, Ro, or ribosomal $P$ antigens. Autoantibodies to nuclear antigens by counterimmunoelectrophoresis were not found in the absence of antinuclear antibodies, and positive reactions by immunoblotting or with cardiolipin were more commonly found in antinuclear antibody positive patients, but the only association which reached statistical significance was antinuclear antibody positivity and positive reactions detected with counterimmunoelectrophoresis using K562 ( $p=0.046)$.

Precipitin lines were seen on immunoblotting

Table 2 Autoantibody profiles of probands by sex, juvenile chronic arthritis onset type, and presence of chronic anterior uveitis. Figures show the number of patients who were positive for a particular investigation

\begin{tabular}{|c|c|c|c|c|c|c|}
\hline & \multirow{2}{*}{$\begin{array}{l}\text { Imamano- } \\
\text { fluorescence } \\
H E_{p-2}(16) t\end{array}$} & \multicolumn{2}{|l|}{$C I E^{*}$} & \multicolumn{2}{|c|}{ Imemunoblotting } & \multirow{2}{*}{$\begin{array}{l}E L I S A^{*} \\
\overline{A C L^{*}(7)}\end{array}$} \\
\hline & & $\operatorname{RTE}^{*}$ (4) & $K 562(7)$ & $R T E(4)$ & $K 562(10)$ & \\
\hline $\begin{array}{l}\text { Female }(n=19) \\
\text { Male }(n=4)\end{array}$ & $\begin{array}{r}15 \\
1\end{array}$ & $\begin{array}{l}4 \\
0\end{array}$ & $\begin{array}{l}6 \\
1\end{array}$ & $\begin{array}{l}4 \\
0\end{array}$ & $\begin{array}{l}8 \\
2\end{array}$ & $\begin{array}{l}6 \\
1\end{array}$ \\
\hline $\begin{array}{l}\text { Pauciarticular onset }(n=18) \\
\text { B27 negative }(n=14) \\
\text { B27 positive }(n=4) \\
\text { Polyarticular onset }(n=4) \\
\text { B27 negative }(n=3)\end{array}$ & $\begin{array}{r}12 \\
1 \\
3\end{array}$ & $\begin{array}{l}2 \\
0 \\
2\end{array}$ & $\begin{array}{l}5 \\
0 \\
2\end{array}$ & $\begin{array}{l}4 \\
0 \\
0\end{array}$ & $\begin{array}{l}8 \\
1 \\
1\end{array}$ & $\begin{array}{l}6 \\
1 \\
0\end{array}$ \\
\hline Presence of $\mathrm{CAU}^{*}(n=10)$ & 8 & 1 & 5 & 3 & 5 & 5 \\
\hline
\end{tabular}

*CIE=counterimmunoelectrophoresis; ELISA=enzyme linked immunosorbent assay; RTE= rabbit thymus extract; $\mathrm{ACL}=$ anticardiolipin antibodies; $\mathrm{CAU}=$ chronic anterior uveitis.

tSubstrate (number positive) is shown. 
Table 3 Comparison of tests for autoantibodies in patients with juvenile chronic arthritis. Figures show the number of patients who were positive for the investigations indicatedf

\begin{tabular}{|c|c|c|c|c|c|c|c|}
\hline \multirow[t]{2}{*}{ Test } & \multirow[t]{2}{*}{ Substrate } & \multirow{2}{*}{$\begin{array}{l}\text { Immuno- } \\
\text { fluorescence } \\
H E p-2(16) t\end{array}$} & \multicolumn{2}{|l|}{$C I E^{*}$} & \multicolumn{2}{|c|}{ Immunoblotting } & \multirow{2}{*}{$\begin{array}{l}E L I S A^{*} \\
\overline{A C L^{*}(7)}\end{array}$} \\
\hline & & & $R T E^{*}(4)$ & K562 (7) & RTE (4) & $K 562(10)$ & \\
\hline $\begin{array}{l}\text { Immunofluorescence } \\
\text { CIE } \\
\text { Immunoblotting }\end{array}$ & $\begin{array}{l}\text { HEp-2 } \\
\text { RTE } \\
\text { K562 } \\
\text { RTE } \\
\text { K562 }\end{array}$ & & 4 & $\begin{array}{l}7 \\
3\end{array}$ & $\begin{array}{l}3 \\
1 \\
2\end{array}$ & $\begin{array}{l}7 \\
2 \\
3 \\
1\end{array}$ & $\begin{array}{l}6 \\
0 \\
4 \\
1 \\
4\end{array}$ \\
\hline
\end{tabular}

${ }^{*} \mathrm{CIE}=$ counterimmunoelectrophoresis; ELISA = enzyme linked immunosorbent assay; RTE= rabbit thymus extract; ACL=anticardiolipin antibodies.

tSubstrate (number positive) is shown.

$\ddagger$ None of the associations reached statistical significance.

in 13 of $23(57 \%)$ patients with JCA. Five of 23 patients $(22 \%)$ had bands in the $43-45 \mathrm{kD}$ range, and 4/23 (17\%) had bands in the 30-35 $\mathrm{kD}$ range using $\mathrm{K} 562$ substrate (total range of banding 25-50 kD). No common banding patterns were seen on rabbit thymus extract immunoblotting (range of banding 29-80 kD). In total, only three patients (13\%) (two of whom were HLA-B27 positive) did not have any evidence of autoantibodies to nuclear antigens or cardiolipin.

Immunoblotting showed common banding patterns between family members and probands with JCA in five families (rabbit thymus extract: one family, $60 \mathrm{kD}$ bands; K562: four families, $33,35,37$, and $45 \mathrm{kD}$ bands respectively). The nature of the bands was not further characterised. None of these five families had banding patterns in common between the father and the mother. There were also similarities in antinuclear antibody patterns on indirect immunofluorescence (three families), antibodies to rabbit thymus extract (counterimmunoelectrophoresis; three families), and antibodies to K562 (counterimmunoelectrophoresis; five families). Lines of identity were seen between two members of one family on counterimmunoelectrophoresis using K562.

\section{Discussion}

The presence of autoantibodies in 39/66 (59\%) of the immediate family relatives of patients with JCA, with shared family patterns of banding, immunofluorescence, and precipitation, provides evidence for an inherited basis to the immunoregulatory abnormalities seen in JCA. This finding has not been previously reported as far as we know, though the autoantibodies associated with other autoimmune diseases have been found in asymptomatic family members ${ }^{19213738}$ and related to the inheritance of certain HLA haplotypes. AntiRo, anti-DNA, and rheumatoid factor were associated with HLA-DR2 or HLA-DR3 in patients with systemic lupus erythematosus, ${ }^{17}$ and anticentromere antibody was associated with DRl in patients with progressive systemic sclerosis and their immediate family relatives. ${ }^{20}$ Environmental factors alone are unlikely to account for the familial prevalence of autoantibodies noted in our study because none of the parental partners had common banding patterns on immunoblotting, including those from the five families who had banding patterns in common with the proband with JCA. In addi- tion, the prevalence of antinuclear antibodies noted in the families from our study (14\%) was much higher than that expected in the general Australian population (3.5\%). ${ }^{39}$ Clemens et al reported that HLA-DR5 was associated with antinuclear antibodies in sibling pairs with JCA. ${ }^{28}$ The subjects in our study did not have full HLA typing. The relation between autoantibodies and the HLA haplotypes associated with the families of children with chronic arthritis remains to be elucidated.

There is other evidence that families of arthritic children are predisposed to autoimmunity. A survey of 888 first degree relatives of 64 probands with juvenile rheumatoid arthritis found a significantly increased prevalence of autoimmune diseases such as systemic lupus erythematosus and adult rheumatoid arthritis. ${ }^{30}$ Juvenile arthritis was associated with a high prevalence of insulin dependent diabetes mellitus in a large inbred kindred in Canada. ${ }^{24}$ There have been several reports of concurrence of childhood arthritis among twins, ${ }^{25} 40$ siblings, ${ }^{2829}$ and other family members. ${ }^{23}$ The association of juvenile arthritis with HLA-A2, DR5, DRw8, and DPw2 ${ }^{2}{ }^{26} 27$ also provides support for a genetic basis to JCA. It should be noted, however, that multiple sibships with JCA are uncommon ${ }^{42}$ and concordance for juvenile rheumatoid arthritis was found in only $3 / 10$ monozygotic twin pairs, ${ }^{43}$ suggesting that other precipitating factors play a part.

We found serological evidence of autoimmunity in $20 / 23$ patients $(87 \%)$. Seventy per cent $(16 / 23)$ of our patients were antinuclear antibody positive in this study. This percentage was similar to those previously reported in other studies of children with chronic arthritis. ${ }^{2-48}$ Comparisons of this nature might be improved if one set of diagnostic/classification criteria for children with arthritis was used instead of the current diverse definitions. ${ }^{33} 44$

Countercurrent immunoelectrophoresis with rabbit thymus extract showed few positive reactions (4/23), in keeping with results reported by Alspaugh, ${ }^{45}$ Moore, ${ }^{13}$ and Malleson. ${ }^{32}$ Positive reactions using the K562 substrate were more commonly found (7/23). The use of this substrate to assess autoimmunity in patients with JCA has not been previously reported. Substrates such as calf thymus extract have been shown to be cheaper and superior to rabbit thymus extract in precipitation line resolution, and stability, ${ }^{46}$ and perhaps K562 represents a similar substrate. 
Immunoblotting seems to be a more sensitive technique than counterimmunoelectrophoresis for characterising antinuclear antibodies, ${ }^{47}$ but despite using immunoblotting and K562 substrate we were unable to show any banding patterns common to all or even most of our patients. Precipitation lines were most commonly seen in the $43-45 \mathrm{kD}(22 \%)$ and $30-35$ $\mathrm{kD}(17 \%)$ ranges. Using an HEp-2 extract, Malleson et al found common IgG precipitation lines at $33 / 35$ and $45 \mathrm{kD}(24 \%$ and $14 \%$ of patients respectively). ${ }^{32}$ The doublet at $33 / 35$ was thought to represent antihistone $\mathrm{Hl}$ reactivity, and we found similar doublets in two of our patients. Antibodies to histone have also been shown in about $50 \%$ of serum samples from children with chronic arthritis by immunoblotting, ${ }^{48}$ and by an ELISA technique. ${ }^{31}$ Reactivity to a $70 \mathrm{kD}$ component of a saline extract of beef spleen was reported in $59 \%$ of patients with juvenile arthritis, ${ }^{49}$ and more recently the same group reported that $63 \%$ of antinuclear antibody positive serum samples from patients with juvenile rheumatoid arthritis react with two bands $(50-40 \mathrm{kD})$ from a saline extract of HeLa cells. ${ }^{50}$ These studies further illustrate the influence of the immunoblotting substrate on the molecular weight of the nuclear antigens recognised by JCA autoantibodies. The detection of common antigenic specificities of antinuclear antibodies associated with JCA may require testing of different nuclear substrates, refinement of immunological techniques, and possibly an improvement of the clinical subclassification of patients with JCA. ${ }^{51}$

Anticardiolipin antibodies were detected in $30 \%(7 / 23)$ of our patients, a percentage similar to the $42 \%$ ( $5 / 12$ patients) reported by Shergy $e t$ $a l .{ }^{52}$ The significance of these autoantibodies in JCA is unclear. None of our anticardiolipin antibody positive patients has had any clinically apparent thrombotic episodes, the feature which most commonly links adult patients with antiphospholipid antibodies. ${ }^{53} 54$ Interestingly, $33 \%$ of a series of adult patients with rheumatoid arthritis had anticardiolipin antibodies, but no significant correlation with recurrent thrombosis could be found. 55

Our results have highlighted the occurrence of autoantibodies in other family members of patients with JCA, though we have not been able to define a specific autoantibody common to all of our patients. Future research in this area may increase our understanding of the genetic basis of JCA.

The authors gratefully acknowledge all the patients with juvenile chronic arthritis and their families who contributed blood for this study, the Arthritis Foundation of Australia and the National Health and Medical Research Council for financial assistance, Dr Health and Medical Research Council for financial assistance, $\mathrm{Dr}$
A Hohmann for the results from the anticardiolipin assay, $\mathrm{Dr} M$, A Hohmann for the results from the anticardiolipin assay, Dr M,
MacKinnon of the Statistical Advisory Service of British Columbia's Children's Hospital Research Centre, and B Sharpe and Petra for secretarial assistance.

1 Petty R E, Cassidy J T, Sullivan D B. Clinical correlates of antinuclear antibodies in juvenile rheumatoid arthritis. antinuciear antibodies in

2 Leak A M. Autoantibody profile in juvenile chronic arthritis. Ann Rheum Dis 1988; 47: 178-82.

3 Osborn T G, Patel N J, Moore T L, Zuckner J. Use of the Hep-2 cell substrate in the detection of antinuclear Hep-2 cell substrate in the detection of antinuclear antibodies in juvenile

4 Rosenberg A M. The clinical associations of antinuclear antibodies in juvenile rheumatoid arthritis. Clin Immunol Immunopathol 1988; 49: 19-27.

5 Rosenberg A M, Hunt D W C, Petty R E. Antibodies to native type I collagen in childhood rheumatic diseases. f Rheumatol 1984; 11: 421-4.

6 Rosenberg A M, Hunt D W C, Petty R E. Antibodies to native and denatured type II collagen in children with native and denatured type II collagen in children
rheumatic diseases. $₹$ Rheumatol $1984 ; 11: 425-31$.

7 Petty R E, Hunt D W C, Rosenberg A M. Antibodies to type IV collagen in rheumatic diseases. $\mathcal{F}$ R heumatol 1986; 13: 246-53.

8 Haynes D C, Gershwin M E, Robbins D L, Miller III J J, Cosca D. Autoantibody profiles in juvenile arthritis. $\mathcal{J}$ Rhewmatol 1986; 13: 358-63.

9 Borel Y, Morimoto C, Cairns L, Mantzouranis E, Strelkauskas A J, Schlossman S F. Anti-T cell antibody in juvenile rheumatoid arthritis. I Rheumatol $1984 ; 11$ : 56-61.

10 Barron K S, Lewis D E, Brewer E J, Marcus D M, Shearer W T. Cytotoxic anti-T cell antibodies in children with juvenile rheumatoid arthritis. Arthritis Rheum 1984; 27: 1272-80.

11 Morimoto C, Reinhertz E L, Borel Y, Mantzouranis E, Steinberg A D, Schlossman S F. Autoantibody to an immunoregulatory inducer population in patients with juvenile rheumatoid arthritis. F Clin Invest 1981; 67: 753-61

12 Bianco N E, Panush R S, Stillman J S, Schur P H. Immunologic studies in juvenile rheumatoid arthritis. Arthritis Rhewn 1971; 14: 685-96.

13 Moore T L, Osborn T G, Weiss T D, et al. Autoantibodies in juvenile arthritis. Semin Arthritis Rheum 1984; 13: 329-36.

14 Schlumpf U, Howard A, Ansell B M. IgG-Anti-IgG antibodies in juvenile chronic arthritis. Scand $\mathcal{F}$ Rheumatol 1985; 14: 65-8.

15 Petty R E, Hunt D W C, Rollins D F, Schroeder M-L, Puterman M L. Immunity to soluble retinal antigen in patients with uveitis accompanying juvenile rheumatoid patients with uveitis accompanying juvenile
arthritis. Arthritis Rheum 1987; 30: 287-93.

16 Moore T L, Dorner R W. 19S IgM Forssman-type heterophile antibodies in juvenile rheumatoid arthritis. Arthritis Rheum 1980; 23: 1262-7.

17 Ahearn J M, Provost T T, Dorsch C A, Stevens M B, Bias W B, Arnett F C. Interrelationships of HLA-DR, MB, and MT phenotypes, autoantibody expression and clinical features in systemic lupus erythematosus. Arthritis $R$ hewom 1982; 25: $1031-40$.

18 Teitsson I, Thorsteinsson J, Arnason A, Valdimarsson $\mathbf{H}$. Rheumatic diseases in an Icelandic family. Scand $\dot{\mathcal{J}}$ Rheumatol 1985; 14: 109-18.

19 Adamashvili I M, Makarova O V, Kvachadze I M, Trubnikov V I, Zamchuk L A. Antibodies to nucleic acids in systemic lupus erythematosus and rheumatoid arthritis patients and their relatives. Immunol Lett 1983; 6: 33-8.

20 Ruffarri A, Artifone L, Glorioso S, et al. Prevalence of anticentromere antibody in blood relatives of anticentromere positive patients. F R heumatol 1985; 12: 940-2.

21 Lipman S M, Arnett F C, Conley C L, Ness P M, Meyers D A, Bias W B. Genetic factors predisposing to autoimmune diseases: autoimmune hemolytic anemia, chronic thrombocytopenic purpura, and systemic lupus erythematosus. Am I Med 1982; 73: 827-40.
mato

22 Howard J F, Sigsbee A, Glass D N. HLA genetics and inherited predisposition of JRA. $\mathcal{f}$ Rhermatol 1985; 12: $7-12$.

23 Rossen R D, Brewer E J, Sharp R M, Ott J, Templeton J W. Familial rheumatoid arthritis: linkage of HLA to disease susceptibility locus in four families where proband presented with juvenile rheumatoid arthritis. $\mathcal{J}$ Clin Invest 1980; 65: $629-42$.

24 Jaworski M A, Slater J D, Severini A, et al. Unusual clustering of diseases in a Canadian old colony (Choritza) 1988; 138: 1017-25.

25 Aho K, Koshenvuo M, Tuominen J, Kaprio J. Occurrence of rheumatoid arthritis in a nationwide series of twins. $\mathcal{J}$ Rheumatol 1986; 13: 899-902.

26 Hoffman R W, Shaw S, Francis L C, et al. HLA-DP antigens in patients with pauciarticular juvenile rheumatoid arthritis. Arthritis Rheum 1986; 29: 1057-62.

27 Oen K, Petty R E, Schroeder M-L. An association between HLA-A2 and juvenile rheumatoid arthritis in girls. T Rheumatol 1982; 9: 916-20.

28 Clemens L E, Albert E, Ansell B M. Sibling pairs affected by chronic arthritis of childhood: evidence for a genetic predisposition. I R heumatol 1985; 12: 108-13.

29 Rosenberg A M, Petty R E. Similar patterns of juvenile reumatoid arthritis within families. Arthritis Rherom 1980 23: 951-3.

30 Church J L, Bernstein B, Church J A, Hanson V. Familial prevalence of immunologically-mediated diseases (IMD) in juvenile rheumatoid arthritis (JRA) [Abstract]. Arthritis Rheum 1983; 26 (suppl): S85.

31 Ostensen M, Fredriksen K, Kass E, Rekvig O-P. Identification of antihistone antibodies in subsets of juvenile

32 Malleson P N, Petty R E, Fung M, Candido E P M. Reactivity of antinuclear antibodies with histones and other antigens in juvenile rheumatoid arthritis. Arthritis Rheum 1989; 32: $990-4$.

33 Wood P H. Nomenclature and classification of arthritis in children. In: Munthe E, ed. The care of rheumatic children. Basel: EULAR, 1978: 47-50.

34 Friou $G$ J. Fluorescent spot test for anti-nuclear antibodies. Arthritis Rhewm 1962; 5: 407-10.

35 Sutjita M, Hohmann A, Comacchio R, Bradley J. Poly- 
specific human and murine antibodies to diphtheria and tetanus toxoids and phospholipids. Clin Exp I memenonol 1988; 73: 191-7.

36 Towbin H, Gordon J. Immunoblotting and dot immunobinding current status and outlook. I Imomenol Methods 1984; 72: 313-40.

37 Aho K, Sistonen P, Takala J, Sievers K. Genetics of autoantibodies in relation to disease. An epidemiological study of two population series. Acta Med Scand 1982; 211: study of

38 Fennell R H Jr. Maclachlan M J, Rodnan G P. The occurrence of antinuclear factors in the sera of relatives of patients with systemic rheumatic disease. Arthritis $R$ hewam 1962; 5 (suppl): 296.

39 Hawkins R B, O'Connor K J, Dawkins R L, et al. Autoantibodies in an Australian population. 1. Prevalence and persistence. $f$ Clin Lab Immanol 1979; 2: 211-5.

40 Husby G, Williams R C, Tung K S, et al. Immunologic studies in identical twins concordant for juvenile rheumatoid arthritis but discordant for monoclonal gammopathy and amyloidosis. f Lab Clin Med 1988; 111: 307-14.

41 Fujita K, Kobayashi K, Okino F. Juvenile rheumatoid arthritis in two siblings with congenital leucocyte adhesion arthritis in two siblings with congenital leucocy

42 Ansell B M. Juvenile chronic arthritis-families. Dis Markers 1986; 4: 163 .

43 Baum J, Fink C. Juvenile rheumatoid arthritis in monozygotic twins: a case report and review of the literature. Arthritis Rheum 1968; 11: 33-6.

44 Cassidy J T, Levinson J E, Bass J C, et al. A study of classification criteria for a diagnosis of juvenile rheumatoid arthritis. Arthritis Rhewm 1986; 29: 274-81.

45 Alspaugh M A, Miller III J J. A study of specificities of antinuclear antibodies in juvenile rheumatoid arthritis. antinuciear antibodies in
$\mathcal{H}$ Pediatr 1977; 90: 391-5.
46 Collins R J, Neil J C, Druery L N, Wilson R J. Detection of antibodies to extractable nuciear antigens using calf thymus and rabbit thymus. A comparative study of 1000 consecutive antinuclear antibody positive patients. I Immunol Methods 1989; 116: 53-7.

47 Westgeest A A A, van den Brink H G, de Jong J, Swaak A J G, Smeenk R J T. Routine testing for antinuclear antibodies: a comparison of immunofuorescence, counter immunoelectrophoresis and immunoblotting. Fournal of immunoelectrophoresis and imm

48 Pauls J D, Silverman E, Laxer R M, Fritzler M J. Antibodies to histones $\mathrm{HI}$ and $\mathrm{HS}$ in sera of patients with juvenile rheumatoid arthritis. Arthritis Rheum 1989; 32: 877-83.

49 Osborn T G, Smith K R, Haber P L, Moore T L Characterisation of a saline extractable antigen reactive with juvenile rheumatoid arthritis sera [Abstract]. Arthritis Rhewm 1987; 30 (suppl): 126.

50 Haber P L, Osborn T G, Moore T L. Antinuclear antibody in juvenile rheumatoid arthritis sera reacts with $50-40 \mathrm{kDa}$ antigen(s) found in HeLa nuclear extracts. $\mathcal{f}$ Rheumatol 1989; 16: 949-54.

51 Southwood T R, Petty R E, Malleson P N, et al. Psoriatic arthritis in children. Arthritis Rheum 1989; 32: 1007-13.

52 Shergy W J, Kredich D W, Pisetsky D B. The relationship of anticardiolipin antibodies to disease manifestations in anticardiolipin antibodies to disease manifestations in pediatric syst $1389-94$

53 Hughes G R V, Asherson R A, Khamashta M A. Antiphospholipid syndrome: linking many specialties. Ann Rheum Dis 1989; 49: 355-6.

54 Alarcon-Segovia D. Pathogenetic potential of antiphospholipid antibodies. F Rheumatol 1988; 15: 890-3.

55 Fort J G, Cowchock F S, Abruzzo J L, Smith J B. Anticardiolipin antibodies in patients with rheumatic diseases. Arthritis Rheum 1987; 30: 752-60. 